\title{
The functional complex network approach to foster forest resilience to global changes
}

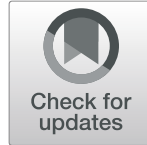

\author{
Christian Messier ${ }^{1,2^{*}}$, Jürgen Bauhus ${ }^{3}$, Frederik Doyon ${ }^{1}$, Fanny Maure ${ }^{2}$, Rita Sousa-Silva ${ }^{1}$, Philippe Nolet ${ }^{1}$, \\ Marco Mina ${ }^{2,4}$, Núria Aquilué ${ }^{2}$, Marie-Josée Fortin ${ }^{5}$ and Klaus Puettmann ${ }^{6}$
}

\begin{abstract}
Human impacts on Earth's ecosystems have greatly intensified in the last decades. This is reflected in unexpected disturbance events, as well as new and increasing socio-economic demands, all of which are affecting the resilience of forest ecosystems worldwide and the provision of important ecosystem services. This Anthropocene era is forcing us to reconsider past and current forest management and silvicultural practices, and search for new ones that are more flexible and better at dealing with the increasing uncertainty brought about by these accelerating and cumulative global changes. Here, we briefly review the focus and limitations of past and current forest management and silvicultural practices mainly as developed in Europe and North America. We then discuss some recent promising concepts, such as managing forests as complex adaptive systems, and approaches based on resilience, functional diversity, assisted migration and multi-species plantations, to propose a novel approach to integrate the functionality of species-traits into a functional complex network approach as a flexible and multi-scale way to manage forests for the Anthropocene. This approach takes into consideration the high level of uncertainty associated with future environmental and societal changes. It relies on the quantification and dynamic monitoring of functional diversity and complex network indices to manage forests as a functional complex network. Using this novel approach, the most efficient forest management and silvicultural practices can be determined, as well as where, at what scale, and at what intensity landscape-scale resistance, resilience and adaptive capacity of forests to global changes can be improved.
\end{abstract}

\section{Introduction}

As with most managed natural ecosystems, forests have been traditionally shaped by human actions and managed to meet human needs and expectations. However, as much as there is a desire to confine them to a narrow scope of conditions, forests are dynamic systems driven by rapidly changing socio-environmental conditions. The speed of global changes (e.g., rapid climate and socio-economic changes, fragmentation of forest landscapes, pollution, introduction of new pests and diseases as well as invasive species, etc.) is creating an increasingly dynamic, uncertain and therefore unpredictable future, making long-term forest planning extremely difficult. Therefore, the current era has been labelled the Anthropocene (Steffen et al. 2007),

\footnotetext{
* Correspondence: christian.messier@uqo.ca

${ }^{1}$ Département des sciences naturelles and Institut des sciences de la forêt tempérée (ISFORT), Université du Québec en Outaouais (UQO), 58 rue Principale, Ripon, QC JOV 1V0, Canada

${ }^{2}$ Centre d'étude de la forêt, Université du Québec à Montréal (UQAM), Case postale 8888, succursale Centre-Ville, Montréal, QC H3C 3P8, Canada Full list of author information is available at the end of the article
}

where human impacts on Earth's systems, unexpected and extreme disturbance events, and new and increasing socio-economic demands are strongly compromising the provision of ecosystem services, including those from forests. Faced with this changing future, there are several challenges that need to be incorporated into forest planning:

- Rapidly shifting societal expectations. Our needs and expectations for the different important functions of forests are constantly evolving, difficult to predict, and often incompatible with each other. A shift in emphasis among values and functions of forests (e.g., water regulation over wood and recreation) is happening in many parts of the world. Also, the role of forests in mitigating climate change (via carbon storage in living forests and the lower carbon footprint of using wood over other materials) is receiving more and more attention (Canadell and Raupach 2008; Grassi et al. 2017). 
- Increasing fragmentation of forested landscapes. This is occurring in most cultivated regions of the planet. The overall resilience of smaller and less connected forest patches to natural and man-made disturbances is reduced.

- A gradual loss of forest resilience. Resilience is defined as the ability of a system to resist disturbances or absorb them and rapidly self-reorganize to maintain its main structure and functions. Loss of resilience can be due to biotic (e.g., invasive plant species, exotic pests and diseases) and abiotic (e.g., rapid climatic warming, pollution) factors alone or that can cumulatively interact (Thompson et al. 2009). It can also be due to forest degradation caused by human mismanagement (Chazdon et al. 2017).

- The loss of historical reference conditions. With rapidly changing environmental and biotic conditions, the suitability of using historical reference conditions to manage our forests is reduced (Seastedt et al. 2008). Instead, desired future conditions for forest ecosystems need be derived from the required ecosystem goods and services as well as conservation values.

- An increasing uncertainty in future environmental and socio-economic conditions. This is an integration of the previous arguments and this is due to rapid and compounded environmental, economic and social changes that characterize the so-called Anthropocene making it even harder to understand how forests will respond to future conditions as a socio-ecological system with many feedback loops within and between natural and human systems (Messier et al. 2016).

This paper aims at proposing a comprehensive and flexible new forest management approach to face these challenges where forest's resilience to global changes is increased, while achieving multi-functionality (i.e., ensuring the provision of multiple ecosystems services; Mina et al. 2017) under rapidly changing global environmental and socio-economic conditions. We articulate this approach in continuity with previous forest management paradigms and consequently begin this paper by briefly reviewing the focus and limitations of past and current forest management and silvicultural practices in response to the issues of the Anthropocene. We then follow by reviewing some recent promising concepts that could help achieve these new objectives of managing for multi-functionality and resilience while considering the highly variable and uncertain future socio-environmental conditions. These two reviews led us to propose a novel use of silvicultural interventions that could be implemented at both stand and forest landscape scales, using complex network theory and functional diversity, to efficiently foster resilience to global changes. The approach proposed is generic enough to take advantages of both old and new forestry practices.

\section{Focus and limitations of past and current silvicultural and forest management approaches}

Until a few decades ago, the objective of forest management and silviculture has mainly focused on timber production (Puettmann et al. 2009). Hand in hand with this objective was a major emphasis on increasing forestry efficiency by simplifying forest structures and standardizing forest practices (Puettmann et al. 2009). Mechanization of forest operations has rapidly improved our ability to shape the fate of forests. This resulted in a homogenization of forest conditions across large landscapes to optimize profitability of timber production (more timber/lower extraction costs). This view of the forest as a provision source of raw material for industrial timber products did not change significantly until the latter part of the twentieth century, when society started to acknowledge the other benefits forest ecosystems provide (Bengston 1994). This awareness was supported by scientific knowledge of the complex dynamic of forest ecosystems that has raised questions about the impacts of forestry practices on forest sustainability (Puettmann et al. 2009). As a result, forest management objectives have evolved integrating new values, such as maintaining biodiversity and maximizing carbon sequestration and innovative forestry approaches have been proposed to accomplish this wider range of objectives (Bauhus et al. 2017b).

\section{A variety of approaches for a variety of objectives}

We have grouped past and current silvicultural and forest management approaches into five major categories (Table 1) based on their overriding perspective and management objectives (see also Duncker et al. 2012).

The first category, timber-oriented silvicultural approaches, is strongly weighted towards the continuous production of timber. Practices in this category might differ in terms of compositional and structural heterogeneity, e.g., even-aged or uneven-aged (Nolet et al. 2017), but share a primary economic interest for efficient timber production and a strong control of forest composition and structure. Timber-oriented approaches encompass a variety of silvicultural treatments. For example, in uneven-aged silviculture, trees can be removed individually or in a group with variable cutting cycles and harvest intensity, creating contrasting light conditions within stands and over time. In even-aged silviculture, a clear-cut might be followed by a plantation or it can be implemented to protect and release advance regeneration. Also, a variety of treatments (cleaning, commercial and pre-commercial thinning, etc.) can be used to various degrees of intensity throughout 
Table 1 Major silvicultural and forest management approaches in Europe and North America. They are grouped into five categories: timber-oriented, nature-based, global change, landscape, and conceptual. These general banners reflect the main features of the approaches as defined in the associated literature. Each approach is classified according to their main management goals (maximum two), as taken from literature. Additional benefits that might be achieved but are not targeted themselves are marked with a cross. For instance, the main objective of uneven-aged forestry is to produce large volumes of timber, but the maintenance of ecological diversity is also considered important in this approach (Nolet et al. 2017)

\begin{tabular}{|c|c|c|c|c|c|c|c|c|c|c|}
\hline \multirow{2}{*}{\multicolumn{2}{|c|}{$\begin{array}{l}\text { Silvicultural and forest } \\
\text { management approaches }\end{array}$}} & \multicolumn{6}{|c|}{ Management goals } & \multicolumn{2}{|l|}{ Where? } & \multirow[t]{2}{*}{ Key references } \\
\hline & & $\begin{array}{l}\text { Timber } \\
\text { and biomass }\end{array}$ & Biodiversity & Resilience & $\begin{array}{l}\text { Carbon } \\
\text { storage }\end{array}$ & $\begin{array}{l}\text { Social } \\
\text { acceptance }\end{array}$ & $\begin{array}{l}\text { Water } \\
\text { quality }\end{array}$ & Europe & $\begin{array}{l}\text { North } \\
\text { America }\end{array}$ & \\
\hline \multirow[t]{12}{*}{ Stand-level } & Timber-oriented & & & & & & & & & \\
\hline & $\begin{array}{l}\text { Even-aged } \\
\text { stand systems }\end{array}$ & 1 & & & + & & & $x$ & $x$ & $\begin{array}{l}\text { Kuuluvainen et al. 2012; } \\
\text { Nolet et al. } 2017\end{array}$ \\
\hline & $\begin{array}{l}\text { Uneven-aged } \\
\text { stand systems }\end{array}$ & 1 & + & + & + & + & & $x$ & $x$ & $\begin{array}{l}\text { Kuuluvainen et al. 2012; } \\
\text { Nolet et al. } 2017\end{array}$ \\
\hline & $\begin{array}{l}\text { Short-rotation } \\
\text { forestry }\end{array}$ & 1 & & & & & & $x$ & $x$ & Weih 2004 \\
\hline & Nature-based & & & & & & & & & \\
\hline & $\begin{array}{l}\text { Close-to-nature } \\
\text { forestry }\end{array}$ & 2 & + & + & & 1 & & $x$ & & $\begin{array}{l}\text { Jacobsen 2001; } \\
\text { Bauhus et al. } 2013\end{array}$ \\
\hline & $\begin{array}{l}\text { Continuous } \\
\text { cover }\end{array}$ & 1 & + & & & 2 & & $x$ & & $\begin{array}{l}\text { Pommerening and } \\
\text { Murphy } 2004\end{array}$ \\
\hline & $\begin{array}{l}\text { Retention } \\
\text { systems }\end{array}$ & 1 & 2 & + & & + & & $x$ & $x$ & $\begin{array}{l}\text { Mitchell and Beese 2002; } \\
\text { Lindenmayer et al. } 2012\end{array}$ \\
\hline & $\begin{array}{l}\text { Ecological } \\
\text { forestry }\end{array}$ & 1 & 2 & & & + & & & $x$ & $\begin{array}{l}\text { Seymour and Hunter 1999; } \\
\text { Franklin et al. } 2007\end{array}$ \\
\hline & Global-change dri & iven & & & & & & & & \\
\hline & $\begin{array}{l}\text { Adaptive } \\
\text { silviculture }\end{array}$ & 2 & & 1 & & + & & & $x$ & $\begin{array}{l}\text { Nagel et al. 2017; } \\
\text { Halofsky et al. } 2018\end{array}$ \\
\hline & $\begin{array}{l}\text { Climate-smart } \\
\text { forestry }\end{array}$ & + & & 2 & 1 & & & $x$ & & Nabuurs et al. 2017 \\
\hline \multirow[t]{5}{*}{$\begin{array}{l}\text { Landscape- } \\
\text { level }\end{array}$} & $\begin{array}{l}\text { Sustainable } \\
\text { yield forestry }\end{array}$ & 1 & & & & & & $x$ & $x$ & Wiersum 1995 \\
\hline & $\begin{array}{l}\text { Functional } \\
\text { zoning }\end{array}$ & 2 & + & + & & 1 & & & $x$ & $\begin{array}{l}\text { Seymour and Hunter 1992; } \\
\text { Messier et al. } 2009\end{array}$ \\
\hline & $\begin{array}{l}\text { Ecosystem } \\
\text { management }\end{array}$ & 1 & 2 & + & & + & & & $x$ & $\begin{array}{l}\text { Kohm and Franklin 1997; } \\
\text { Bergeron et al. } 1999\end{array}$ \\
\hline & $\begin{array}{l}\text { Sustainable } \\
\text { forestry }\end{array}$ & + & 2 & + & + & 1 & + & $x$ & $x$ & $\begin{array}{l}\text { Aplet et al. 1993; } \\
\text { Oliver } 2003\end{array}$ \\
\hline & $\begin{array}{l}\text { Multi-purpose } \\
\text { forestry }\end{array}$ & 1 & + & & + & 2 & + & $x$ & $x$ & Lexer and Brooks 2005 \\
\hline \multirow{3}{*}{$\begin{array}{l}\text { Conceptual- } \\
\text { level }\end{array}$} & New forestry & 1 & + & 2 & & & & & $x$ & Franklin 1989 \\
\hline & Holistic forestry & 2 & + & & & 1 & & & $x$ & Pinkerton 1998 \\
\hline & $\begin{array}{l}\text { Systemic } \\
\text { silviculture }\end{array}$ & + & 1 & 2 & & & & $x$ & & Ciancio and Nocentini 2011 \\
\hline
\end{tabular}

production cycles. In the second category, nature-based silvicultural approaches, the focus shifts towards incorporating natural processes into management or to using natural processes to guide management. This often focusses less on economic values and more on ecological and cultural values, although some elements of this approach such as natural regeneration or self-pruning of trees might have originally been motivated by cost-savings (Puettmann et al. 2009; Duncker et al. 2012; O'Hara
2016). A nature-based silviculture rests therefore on the assumption that, by emulating nature, management and harvesting can reduce the impact of disturbances on ecosystem functions and biodiversity and that natural processes can be employed to achieve silvicultural goals (Bauhus et al. 2013; O’Hara 2016). Attaining a high level of social acceptance is also a key element distinguishing these approaches from intensive harvesting systems. More recently some approaches in our third silvicultural 
and forest management category, which we refer to as global-change driven approaches, have been developed to explicitly integrate the challenges and opportunities of climate change into forest management. These approaches reflect notions that nowadays silviculture and forest management should account not only for ecological, economic and social issues, but also promote forest resilience to climate change, while maintaining the whole forestry value chain. For instance, in North America, a number of adaptation frameworks, built upon on science-management partnerships, have currently been implemented on-the-ground by the Canadian and US forest agencies to identify optimum combination of already-existent measures to prepare forests to climate change (e.g., Halofsky et al. 2016; Nagel et al. 2017); for a review, see Halofsky et al. (2018). In Europe, Climate Smart Forestry, a similar concept to the Climate-Smart Agriculture concept developed by FAO, has been suggested to safeguard the mitigation potential of forests against climate change through an array of regionally tailored measures (Nabuurs et al. 2017). However, these approaches are still far from being mainstream and building forest resilience to climate change has not yet become a common driver of forest management activities.

While most silvicultural approaches may contribute to various non-timber goals (e.g., biodiversity, carbon storage, and societal acceptance), these are rarely their main goals (Table 1). Shifting focus from primarily the stand to the landscape scale, various approaches can be combined in a manner that can satisfy diverse needs and goals. Multi-purpose forestry and functional zoning are two examples of such landscape-level forest management approaches, our fourth category (Table 1). Multi-purpose forestry requires forest managers to consider a broad range of ecosystem attributes, at various spatial and temporal scales, when designing management strategies and monitoring their outcomes. This may include trade-off relationships among conflicting management objectives (Lexer and Brooks 2005). When this integrated management method was first proposed, it was expected to maximize all the values locally, even in the same stand, at the same time (Behan 1967). However, it has been rapidly acknowledged that potential and constraints for enhancing specific values differ across a landscape, so that maintaining all values everywhere would not be optimal (Vincent and Binkley 1993). This attempts to simultaneously integrate multiple forest functions with the functional zoning approach, such as the TRIAD concept (Messier et al. 2009). Functional zoning suggests dividing forests into a number of zones for different, but complementary uses, such as timber production, biodiversity conservation, and multiple use forestry (Seymour and Hunter 1992). Functional zoning offers the opportunity to incorporate a wide variety of societal values into forest management activities.
In the fifth category, conceptual forest management approaches, we have grouped approaches based on concepts and purposes that go beyond the recommendation of specific management practices, or advance specific silvicultural systems. Examples include New Forestry (Franklin 1989), Holistic Forestry (Pinkerton 1998), and Systemic Silviculture (Nocentini et al. 2017). These approaches often served as a novel paradigm for defining new conceptual frameworks and ethical perspectives on forest management. For instance, New Forestry thinking has emerged as a unique perspective for dealing with an increased public concern over environmental issues, such as biodiversity decline in managed forests, shifting the focus from tree harvesting revenue to ecological legacies left after harvest.

As different as they are, most of the approaches described above assume that trees and forests can continue to grow in the future as they did in the past, that it is possible to predict what will be the desirable tree species for the future and that a relatively strong command and control over forest management and silviculture is desirable. Consequently, these approaches are not individually well adapted to the increasing environmental and socio-economic uncertainties associated with the Anthropocene.

\section{Promising approaches and concepts for the future}

In this section, we review recent approaches and concepts that we consider useful for the development of the novel functional complex network approach proposed in the section "The functional complex network approach". This brief discussion is meant to provide readers with enough background to understand how the new approach could be designed.

\section{Managing forests as complex adaptive systems: overcoming the command and control approach}

Viewing forests as complex adaptive systems is not a management approach per se and does not lend itself to simple rules or recipes reflected in stand prescriptions. Instead, Puettmann et al. (2009) suggested it as an alternative to applying the "homogeneity equals efficiency" paradigm to forestry, and thus encouraged forestry to deviate from or move beyond the agricultural production model. As such, the emphasis on adaptation in complex systems theory can be viewed as an inspiration for our integrated approach described below. In practical terms, integrating this viewpoint into management practices can be accomplished by incorporating information about characteristics of complex adaptive systems, e.g., uncertainty, non-linearity and threshold behaviour, bottom-up control through cross-scale hierarchies (Peters et al. 2011; Filotas et al. 2014), in the development and assessment of management decisions (Messier et al. 2015; Puettmann et 
al. 2016). Consequently, viewing forests through this novel lens can be applied to any forest management and/or silvicultural approach (Fahey et al. 2018). At the same time, applying a mixture of silvicultural approaches simultaneously to accommodate the variety of ecological conditions and social expectations can be viewed as a response to the new insights derived from viewing the forest as a complex adaptive system (Messier et al. 2013).

For several reasons, forests are a prime example of complex adaptive systems (Filotas et al. 2014). Firstly, the formal recognition of the link between ecological and social components constitutes a major distinction between viewing forests as a complex adaptive system and other management approaches (Messier et al. 2015). This results in the acceptance that in many situations, the challenges faced by forest management are a wicked problem with no optimal solution (DeFries and Nagendra 2017).

Secondly, the acceptance that uncertainty is an inherent part of an ecosystem pushes foresters to place more emphasis on the forest natural adaptive capacity. This is based on the recognition that adaptive capacity is necessary to allow forest ecosystems to respond to unexpected events and to continue ensuring the provision of desired functions and services (Puettmann 2014), especially in an increasingly uncertain future. This aspect is reflected in the appreciation of the value of variability and diversity as key components for adaptive capacity (Conrad 1983). Thus, they become prominent considerations in silvicultural prescriptions.

Thirdly, relying more on the ability of ecosystems to respond to unexpected and compounded perturbations also reflects the fact that complex adaptive systems are driven from the bottom up. The behaviour of these systems is determined by a collection of heterogeneous individual components that interact across hierarchical scales, including feedback loops, in nonlinear and threshold relationships. This underscores the importance of maintaining or enhancing the diversity component as well as their interactions ("keep every cog and wheel," sense Aldo Leopold). However, it is not simply more diversity or variability that is required, but the right assemblages of components that functionally generate more resilient ecosystems. The emphasis on multi-hierarchical interactions among components also highlights the notion of emergent properties, which relates to the role of unpredictability as an integral part of complex ecosystem behaviour (Valiente-Banuet et al. 2015).

Fourthly, considering management decisions and their impact across various scales from local neighbourhoods to landscapes (Puettmann and Tappeiner 2013), and systems from ecological to administrative (DeFries and Nagendra 2017), there is an argument in favour of the need for more flexibility for foresters to prepare for unpredictability. For example, assessing management success, such as reforestation standards or carbon storage, at landscape scales may allow for variability within and among stands. This variability may permit foresters to let natural processes play out and allow ecosystems to self-organize and thus adapt to changing conditions, e.g., through natural regeneration.

Lastly, assessing ecosystem responses in the context of non-linear and threshold behaviour further emphasizes self-organization. This assessment highlights where specific management treatments are needed and would optimize achievement of ownership goals. Putting all these aspects together and acknowledging the importance of cross-scale hierarchical interactions and recognizing that complex adaptive systems are "open", i.e., forestry is part of a socio-ecological system, emphasizes the importance of assessing a multitude of ecosystem functions and services at multiple scales (Messier et al. 2015). A broad array of public influences, perceptions, and expectations that are linked to a wide range of ecosystem services cannot be ignored, even for private landowners who may often have fairly narrow objectives. Only when all players in the socio-ecological system are properly acknowledged and their views and values are integrated into management decisions will forestry be able to keep the "license" to operate in the long run.

\section{Mixed forests and plantations: providing insurance against global changes}

Like viewing forests as complex adaptive systems, mixed-species forests and plantations are also not a forest management or silvicultural approach per se. However, mixing tree species in forest stands and landscapes is a central element of most alternative silvicultural approaches and strategies to incorporate the notion of the insurance hypothesis (Yachi and Loreau 1999) to better prepare forests for the uncertainties derived from global changes (Puettmann et al. 2015; Bauhus et al. 2017b). The maintenance and promotion of tree species mixtures is based chiefly on three motivating factors: a higher provision of ecosystem goods and services, lower risks following disturbances such as pests and diseases, and higher degree of adaptability than would be possible with mono-specific stands (Pretzsch et al. 2017). Mixing tree species can basically be integrated into all forms of current forest management and silvicultural practices, from close-to-nature forests (which already emphasizes mixtures) to intensively managed plantations.

There is now substantial evidence that mixed species stands are on average more productive in terms of biomass than their monospecific counterparts (Liang et al. 2016). For many other ecosystem services there is increasing evidence that they are also positively related to tree species richness, but the mixing effect is more variable and less clear (Gamfeldt et al. 2013). While particular ecosystem services may be provided to a higher degree in 
specific monocultures, mixtures are better suited to provide multiple ecosystem services, where each service may be provided at a somewhat reduced degree compared to monocultures specifically focussed on the respective ecosystem service; a phenomenon termed the "Jack-of-all-trades-effect" of mixtures (van der Plas et al. 2016). This effect appears to be particularly important in contexts such as publicly owned forests managed on long rotations, where it is highly unpredictable which ecosystem services future generations may wish to obtain from forests and at what level (Bauhus et al. 2017a). Mixtures may thus buffer forest management against changes in societal aspirations and consequently help maintain sustainable forest ecosystems.

In addition, mixed species forests and plantations are more likely to be better able to withstand environmental changes and insect outbreaks than monospecific stands. They have been found to be more resistant in relation to a wide range of stress and disturbance factors (Jactel et al. 2017). This phenomenon is based on two principal effects: (1) the ecological insurance provided in more diverse communities because a high number of functionally different species increases the probability that some of these species are more likely to cope with stress and disturbance (Yachi and Loreau 1999), and (2) the interactions among species that change the way in which an individual species responds to stress and disturbance such that it may be more or less resistant in mixtures than in monocultures (Bauhus et al. 2017a). Whereas there is much evidence for the insurance function of mixtures, the beneficial effects of mixing on individual species appear to be mostly restricted to biological disturbance agents such as specialist insect herbivores and pathogens. Positive examples of mixing on the resistance of individual species are fewer for abiotic disturbances such as wind, fire, and drought (Bauhus et al. 2017a). For some types of disturbances such as insect herbivory, diversity of functionally different tree species in mixtures, e.g., deciduous versus evergreens, has been shown to be more important than mere tree species richness (e.g., Castagneyrol et al. 2014). It is conceivable that this may apply to other stress and disturbance factors as well, but more research is needed.

The higher level of ecosystem services provided by mixed versus monospecific forests suggests that mixed and species rich forests may be a more suitable approach for the ecological intensification of forest management, which aims at providing more goods and services at a reduced environmental footprint (Bauhus et al. 2017c). However, impacts of tree species richness on provision of ecosystem services as well as on ecological stability of forests are highly dependent on context and species assemblage (Ratcliffe et al. 2017). Hence, forests with similar tree species richness but different participating species may differ greatly in their level of ecosystem functioning and even mixed stands with the same species composition may perform differently depending on soil and climatic conditions of the site (Mina et al. 2018). In this context, such dependencies make the outcome of mixed, species-diverse forest stands difficult to predict, which underpins the importance of combining species mixtures with other forest management and silvicultural approaches in the landscape.

\section{Functional diversity: a new way of managing tree diversity in forests}

The maintenance of a high species and structural (stands of different age or structures) diversity in forested landscapes have been proposed as essential for maintaining high resilience of natural ecosystems (Messier et al. 2013; Seidl et al. 2016; Timpane-Padgham et al. 2017). Although the number of different species gives us a good indication of diversity of a community, it does not provide specific information about the diversity of biological functions and ecological services provided by the species present, nor about which ecological niches are occupied or not. A relatively recent approach has advocated the use of biological characteristics of species known as functional traits (Violle et al. 2007) to better characterize ecosystem diversity. Functional traits can be defined as any biological characteristic that can be easily measured and that influence the performance of an individual in terms of growth, survival or reproduction of the species (Violle et al. 2007). For trees, specific functional traits for adapting to climate change and coping with disturbance (drought, fire, wind, etc.) include tree height, wood structure and density, seed size, specific leaf area, ability to resprout, bark thickness, and rooting depth (Aubin et al. 2016). Communities with both a mixture of traits that enable species to adapt to known stressors referred to as functional (or response) diversity - as well as a high recurrence of traits that allow species to adapt to unknown stressors - referred to as functional redundancy will more likely be resistant, resilient or able to transit to another desirable well-adapted community (Yachi and Loreau 1999; Laughlin et al. 2017) (Fig. 1). Facing global changes leading to uncertain social and environmental conditions, a resilient forest must be composed of tree species with diverse functional traits that can withstand or adapt to the widest possible spectrum of stress (Fig. 1a). To complete this resilience, several species have to share the same functional traits in order to maintain a good diversity of traits in case some species are lost from the system (Fig. 1b).

A simple method of including the functional approach into forest management plans is to group tree species according to the similarity of their functional response traits, creating functional groups (Aubin et al. 2007). For example, shade-tolerant species with high wood density and relatively large seed size will be included in the same group, while shade-intolerant species with low wood 
density and small seed size will form a different group. Each of these groups is characterized by a specific growth strategy and presents specific responses and adaptations to stress and disturbances and change in the environment. Forests with tree species covering the widest possible range of functional groups in more or less equal proportions and with some functional redundancy will be better prepared to face a wide variety of present and future stressors.

\section{Assisted migration of tree species: bringing new traits and genes to cope with global changes}

Since prehistoric times, humans have contributed to the dispersal of many important plants and tree species within and across continents (Ridley 1930). During the past centuries, there have been extensive plantations of exotic timber species such as Douglas fir and Sitka spruce in Europe, and the introduction of non-native tree and plant species in Eastern North America (Schulz and Gray 2013). With the advent of the Anthropocene, several studies have demonstrated that many plant species will likely be unable to adapt or migrate fast enough to new areas with suitable climate to cope with rapid changes in climate (Sittaro et al. 2017). Assisted migration, the human-mediated movement of species, genotypes or provenances to locations that better match them climatically in the future, has been proposed as a potential adaptive strategy in response to the changing climate (Williams and Dumroese 2013). Depending on the spatial scale of the translocation of individuals, assisted migration has been described as assisted population migration, assisted range expansion and assisted species migration (see Fig. 2). According to the literature, the scientific community is somewhat divided on the implementation of the different assisted migration options in forest landscapes. In forestry circles, assisted migration is regarded as a tool to maintain optimum productivity in commercial forests and to preserve market-based ecosystem services by preventing current species from becoming maladapted to future climate. Conservationists look at assisted migration as the ultimate resource for rescuing endangered species or rear-edge marginal populations from extinction and are generally against its extensive implementation, citing potential negative risks, such as cryptic maladaptation, invasiveness and other ecological consequences (Aubin et al. 2011). Pedlar et al. (2012) made a clear distinction between species rescue assisted migration and forestry-based assisted migration. The aim of the first is only to conserve endangered tree species, while the second could be viewed within the larger concept of ecosystem services, with the sole purpose of maintaining a high provision of future goods and services from forest ecosystems. Several authors occasionally have mentioned the idea of using assisted migration to increase forest resilience to global changes and future disturbances (Hof et al. 2017; Park and Talbot 2018). The aim of such "resilience trait-based assisted migration management option" would be to build climate- and disturbance-resilient forests by introducing new functional attributes not present in the natural pool of species to the system. Using functional diversity theory, it can be possible to describe species capacity to respond to new climate conditions as well as to disturbances and new pests (Craven et al. 2016; Duveneck and Scheller 2015). We are aware, however, that assisted migration is a contentious

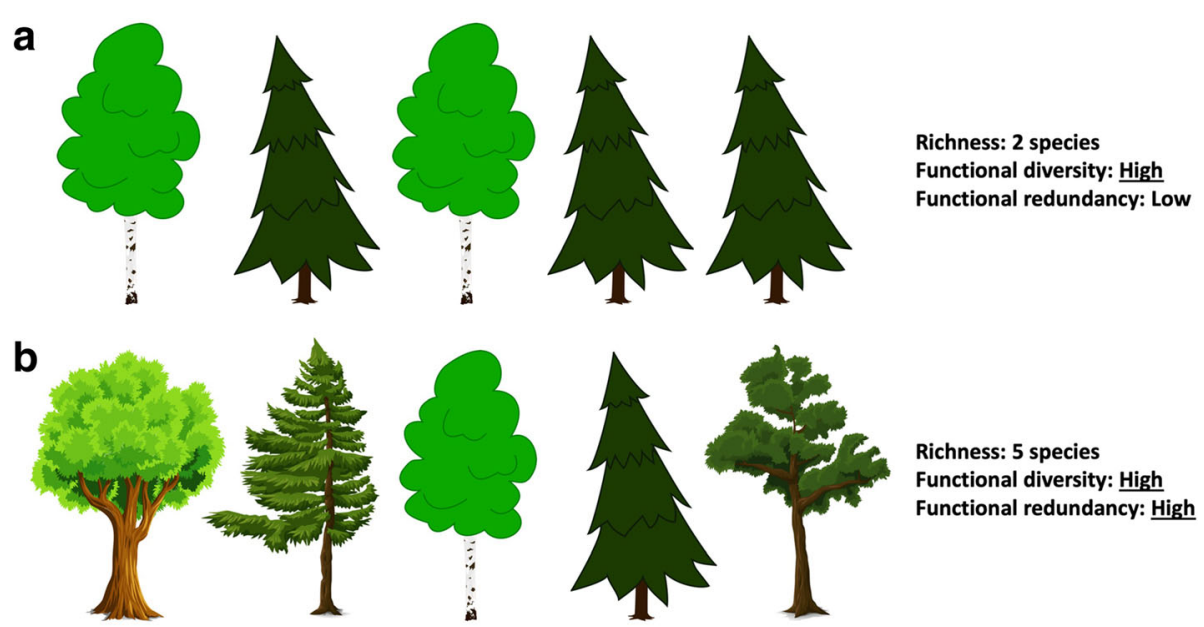

Fig. 1 Diagram illustrating in a simplified way the notions of functional diversity and redundancy within two stands. a Although it consists of only two tree species, the upper stand has a high functional diversity because these two species have very different functional traits: e.g., one species is an angiosperm, the other a gymnosperm. However, because of the large difference in the functional traits between these two species, the functional redundancy is weak and if a species disappears, several particular functional traits will be lost. b The lower stand also has a high functional diversity because it is composed of five different species, two gymnosperms and three angiosperms with relatively similar traits. Functional redundancy is however high in this case and if a species disappears, functional traits will be maintained in the stand 


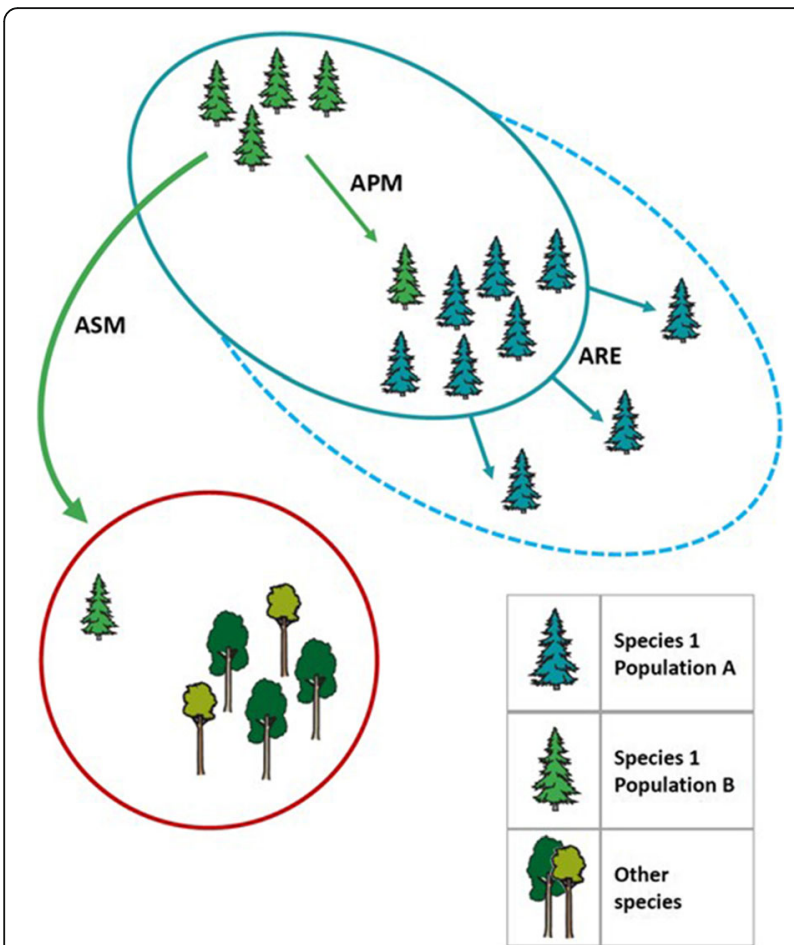

Fig. 2 Conceptualization of the different forms of assisted migration (Park and Talbot 2018). The movement of populations within the current range of a species is generally defined as assisted population migration (APM) while moving individuals of a target species just outside its range to cope with changing environmental conditions is termed as assisted range expansion (ARE). Assisted species migration (ASM) occurs when a species is moved far outside its current distribution range. Less controversial than ASM, APM and ARE have already been adopted in seed transfer guidelines in many regions of the world (Pedlar et al. 2011; Konnert et al. 2015). Although it may involve substantial changes in policy and public perceptions, ASM might be a viable option to introduce specific functional traits and increase resilience in particular forest regions

topic and that its implementation would require acceptance not only within the scientific community but also among social, political, and economic stakeholders (Ste-Marie et al. 2011).

\section{Managing for resilience: acknowledging global changes}

Although forest health and protection have always been two aspects considered in forest management, the increased risk of large-scale disturbances and new stressors brings forest resilience to a new and central position, supplanting many other issues that have been the focus of former paradigms in forestry (D'Amato et al. 2017). In this context, forest resilience becomes an explicit objective of forest management and the focus of specific silvicultural approaches (Lindner et al. 2010). Indeed, managing for resilience has become the new beacon in forestry under many jurisdictions, including in Scandinavia (Chapin et al. 2011) and in the USA (DeRose and Long 2014). One fundamental principle with the resilience management paradigm lies in the acknowledgment that amidst all the rapid global changes happening on Earth, it can no longer be assumed that ecosystem self-regulation and reconstruction after abrupt or continuous forces will occur naturally. However, making the notion of resilience operational for management of forested stands and landscapes has been very challenging. As pioneers, Millar et al. (2007) put resilience in a larger context and proposed a series of options for facing uncertainty using a multi-trajectory approach based on: (1) resistance for forestalling impacts and protecting highly valued resources, (2) resilience for improving the capacity of ecosystems to return to desired conditions after disturbance (ability to bounce back), and (3) response for facilitating ecosystem transition to a stable alternative state under the new conditions (ability to bounce forward). The authors encourage flexible approaches that promote the progressive use of reversible measures, continuous learning, and the maintenance of the ability to change direction when the situation requires it. This approach therefore focuses more on robustness than on optimizing the utilitarian functions of forests. The main issue so far has been a missing harmonized metric for quantifying resilience (Angeler and Allen 2016). Several recent studies have targeted the development of quantifiable resilience indicators. For example, DeRose and Long (2014) presented a conceptual framework for beetle disturbances and proposed stand- and landscape-scale indicators of post-disturbance conditions (e.g., maintenance of mature trees in stands and potential for future spruce dominance across the landscape), while Duveneck and Scheller (2016) used a post-wildfire index based on the recovery rate of species composition and aboveground biomass as a proxy for landscape-scale resilience. Still, it cannot be denied that significant progress has been made lately for measuring and comparing resilience a posteriori (Ingrisch and Bahn 2018). Although substantial effort has been put into developing resilience indicators based on disturbances (Sasaki et al. 2015), these measures have proven to be very difficult to predict, particularly by managers, given the shifting nature of forest ecosystems under global changes as well as the potential occurrence of novel and unpredictable disturbance events (Standish et al. 2014; Seidl et al. 2017). In this context, indices of functional diversity, redundancy and functional connectivity have been increasingly proposed as suitable proxies for quantifying ecological resilience at multiple spatial-scales (Dymond et al. 2014; Standish et al. 2014; Messier et al. 2015).

\section{The functional complex network approach A landscape-level approach for managing forest for resilience in the Anthropocene}

In the section "Focus and limitations of past and current silvicultural and forest management approaches", we 
have described past and current forest management and silvicultural practices in Europe and North America typically implemented at the stand scale to reach desirable, relatively stable tree species composition and structure. Because of the urgent need to develop new approaches to adapt to novel local and global situations, a large variety of forest management and silvicultural approaches are now being used and proposed worldwide from which any forester could choose options that fit their particular needs (Table 1). Hence, we argue that elements from all these approaches could be potentially useful and indeed may be necessary in developing a new flexible and integrated forest management for the Anthropocene. However, a way to integrate them at the appropriate scales has been missing so far, whereby the combination of approaches could be optimized or modified to achieve multi-functionality, while at the same time dealing with uncertainty and increasing or maintaining forest resilience to global changes. Hence, we propose a novel approach to increase forest resilience applied at the landscape scale that can integrate any silvicultural practices developed and applied at the stand/ownership scale (Fig. 3). This approach makes use of two recent developments in ecology: (1) functional traits to evaluate tree functional diversity and redundancy in any forest stand or landscape (Aubin et al. 2016; Aubin et al. 2018), and (2) the adoption of network theory to describe the spatial connectivity of forest stands in terms of seed dispersal and establishment (Fall et al. 2007; Urban et al. 2009; Dale and Fortin 2010). Network theory can be used to evaluate where and how silvicultural interventions should be carried out within the landscape to most efficiently enhance key network properties, namely connectivity, centrality and modularity that all influence resilience.

The integration of these two recent developments into our proposed novel approach is general and flexible enough to be applied in a variety of settings throughout the world, especially in temperate and boreal biomes, by small and large private or public owners, and in forests already under management or previously unmanaged. This new approach attempts to reconcile past, current and newly proposed forest management and silvicultural approaches by considering new scientific knowledge and socio-environmental conditions. It also recognizes various aspects of complex adaptive systems, e.g., the multi-scale organization of forest stands, public or private, within the whole landscape (Fig. 3).

Below we provide an example of how the functional complex network approach can be applied in different forested landscape settings. It is important to note that this approach is nested within a larger social, ecological, and economic context (for brevity not discussed here) which cannot be ignored in real-word applications. Therefore, in this context, we assume that landowners have agreed on a set of goals, and the legal, logistical, and economic feasibility of the treatments.

\section{Managing landscapes as a functional complex network}

Here, we consider forest stands as nodes/patches forming a network representing the functional complexity of forested ecosystems. With such an approach, species-traits diversity at the forest stand level can therefore be more efficiently managed to maintain forest overall functional complexity and consequently its resilience. Several properties (or indicators) can be optimized to manage forest resilience to

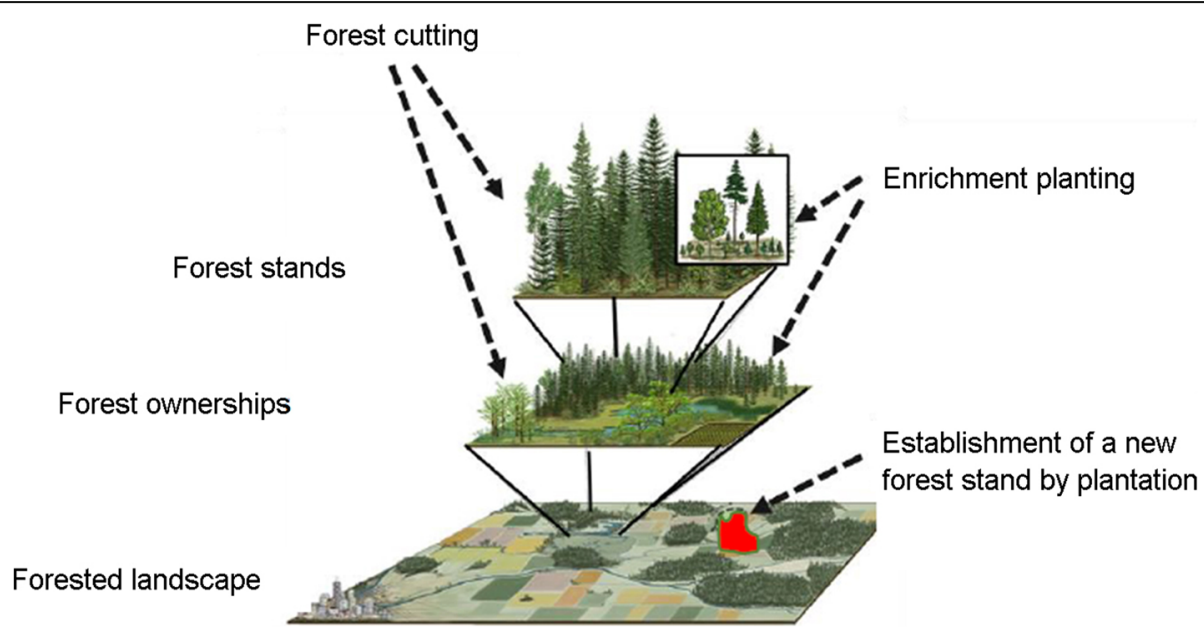

Fig. 3 Conceptual diagram presenting three spatial scales of possible silvicultural intervention: (i) stand, (ii) forest ownership, and (iii) forested landscape. By favouring silvicultural practices through forest cutting, enrichment planting or the establishment of new stands that increase both the functional diversity and redundancy at the scale of the stand and forest ownership, resulting in an enhanced connectivity, centrality and modularity in the surrounding forested landscape, the resilience of the forest network can be greatly promoted (modified from Messier et al. 2018) 
disturbances: functional indices (e.g., diversity and redundancy, among others) and spatial network indices (connectivity, centrality and modularity, among others; see Rayfield et al. 2010). Our approach consists first of calculating the functional attributes of each stand within the forested landscape. Then, the spatial structure of the forest-land network is considered to determine how different patches (i.e., forest stands/ownerships) are connected in regards to seed dispersal and tree establishment capacity to form functional links. Potential functional links exist between patches close enough for tree species to disperse seeds, and account for proportions of intra-stand functional diversity that can travel between stands (according to species dispersal capacity) (as proposed by Craven et al. 2016). The resulting so-called functional network describes spatial distributions of tree communities and their spatial topological layout; it accounts for the whole potential functional diversity of forest landscapes and the likelihood that this functional diversity can disperse across the network, i.e., it quantifies the overall functional connectivity of the landscape (see Craven et al. 2016 for an example of how this is done). We provide an example of how to apply the functional complex network approach to a fictive temperate forest landscape of 100,000 ha (Tables 2 and 3), and how different silvicultural interventions could improve network topology. In this example, three spatial attributes related to the resilience of forest-land network are used: effective connectivity, betweenness centrality (illustrated in Fig. 4), and modularity (Delmas et al. 2018). In a landscape where effective connectivity and centrality are strong (Fig. 4b), biological material (i.e., seed-borne functional traits) can be easily dispersed from one stand to another via multiple possible pathways (Fig. 4b). An effective connectivity ensures a rapid recolonization of disturbed stands by seeds coming from the surrounding intact stands, contributing to a rapid and efficient reorganization of the system. And if the surrounding stands have functionally diverse tree species, the disturbed stands are more likely to regrow a functionally diverse tree community, thus reinforcing the overall resilience of the landscape. "Central" patches within forested landscapes are those having many current or potential connections to neighbouring patches (Fig. 4b) or those connecting otherwise isolated patches in the territory. Central patches usually account for a high functional diversity because either they currently host multiple diverse species (and act as a source of diversity) or they can receive new biological material from functionally rich neighbouring stands. By a structured set of highly central patches, the flow of seeds and genetic material across the landscape is more efficient, improving both overall functional diversity and redundancy. Modularity (not shown in Fig. 4) is obtained when patches are poorly connected to each other (which greatly limits the dispersal of the biological material following a disturbance) or when they are highly connected, but they have a strong functional (i.e., having tree species with
Table 2 Example of a management plan of a fictive temperate forest landscape using the functional complex network approach

The fictive 100,000 ha forested temperate landscape is a simplification of a real landscape found in southern Quebec that is fragmented by croplands, roads and a few small urban areas (based on Aquilué 2018). It includes a large public forest of 30,000 ha and 300 privately owned forests aggregating 5000 forest stands (with mean area values indicated in Table 3). We selected 15 common temperate forest species to estimate the composition of both individual stands and ownership, considering that most stands (75\%) have between 1 and 4 species (up to 10) and most ownerships (75\%) have between 3 and 8 species (up to 12). We assumed equal species abundances on all stands/ownerships and gathered the values of those functional traits contributing to climate change adaptation and disturbance coping for the fifteen-tree species selected (Aubin et al. 2012). Response diversity and functional redundancy indexes (based on species abundances and their functional traits) were calculated following Laliberté and Legendre (2010) and Ricotta et al. (2016) and they were computed at the three working scales (Fig. 3; Table 3). Functional connectivity, centrality and modularity were estimated at the landscape scale before any possible intervention was implemented (Table 3; multiple indexes for these properties are available in the network theory literature (e.g., Newman 2006 and Saura 2010)). As functional diversity, connectivity and centrality were relatively low, a few silvicultural interventions were likely to improve the two functional and three spatial network indices. For this simplified exercise, we added a total of 14,000 new mature trees belonging to 5 species characterized by complementary functional traits on key central forest stands or ownerships, and/or in those less functionally rich stands/properties to the landscape, so to increase both functional diversity and redundancy. Also, we established new forest stands with these 5 new tree species in central areas without forests (Fig. 4). This promoted an increase in both functional diversity and connectivity in the neighbouring forested landscape, while network centrality also improved (Table 3).

different functional traits) and structural (stands of different age or structures) discontinuity. In a strongly modular landscape, it is expected that the propagation of disturbances such as fire, windthrow, diseases and pests would be limited, which is highly desirable. Modularity can also facilitate the identification of groups of forests stands/ ownerships more vulnerable or susceptible to disturbances (provided that a basic knowledge of the disturbance behaviour is known), which would allow to efficiently design prevention plans to such disturbances. Once combined, these five attributes allow for the determination of the overall resilience of a forested landscape to global changes (Aquilué 2018).

Throughout the implementation of this approach, continued assessment of the feasibility and economic and social acceptability of any silvicultural intervention is important. Results of these assessments in turn may lead to changes in management practices to increase response diversity, functional redundancy, connectivity, centrality and modularity in forest landscapes. Thus, while silvicultural interventions are implemented at the stand level, the planning and evaluation of their pertinence and impact are done at the landscape scale. Furthermore, although only a static approach is illustrated in this paper, the values for each of the two functional and three spatial network attributes should be continuously assessed over the whole 
Table 3 Characterization of a simplified national forested landscape of 100,000 ha in an agricultural area through two functional (diversity and redundancy) and three complex spatial network (connectivity, centrality and modularity) indices at three different spatial scales (stand, ownership, and landscape). This territory includes a public forest of 30,000 ha and 300 privately owned forests separated by agricultural fields, roads and small villages. The "landscape after intervention" column provides an example of the improved tree richness, functional indexes and network attributes following targeted silvicultural intervention (see Table 2 for details). Figs. 3 and 4 depict the management plan provided in Table 2

\begin{tabular}{|c|c|c|c|c|}
\hline & Forest stand & Forest patch & $\begin{array}{l}\text { Landscape before } \\
\text { intervention }\end{array}$ & $\begin{array}{l}\text { Landscape after } \\
\text { intervention }\end{array}$ \\
\hline Quantity & 5000 & 300 & 1 & 1 \\
\hline Mean Area (ha) [min, max] & $40[10 ; 120]^{\mathrm{a}}$ & $240[30 ; 500]$ & 100,000 & 100,000 \\
\hline $\begin{array}{l}\text { Mean Richness (nb of tree species) } \pm \text { standard } \\
\text { deviation [min, max] }\end{array}$ & $3 \pm 2[1 ; 10]$ & $6 \pm 3[3 ; 12]$ & 15 & 20 \\
\hline Mean Diversity ${ }^{\mathrm{b}} \pm$ standard deviation $[\mathrm{min}, \max ]$ & $0.21 \pm 0.14[0 ; 0.39]$ & $0.32 \pm 0.03[0.22 ; 0.37]$ & 0.33 & 0.45 \\
\hline Mean Redundancy ${ }^{c} \pm$ standard deviation $[\min , \max ]$ & $0.85 \pm 0.04[0.73 ; 0.99]$ & $0.86 \pm 0.02[0.80 ; 0.93]$ & 0.85 & 0.93 \\
\hline Connectivity ${ }^{c}$ & - & - & 0.45 & 0.81 \\
\hline Centrality $^{\mathrm{b}}$ & - & - & 1.27 & 3.67 \\
\hline Modularity ${ }^{c}$ & - & - & 0.53 & 0.39 \\
\hline Resilience of landscape & - & - & Low & High \\
\hline
\end{tabular}

${ }^{a}$ Mean value \pm standard deviation [minimum; maximum]

${ }^{b}$ No superior limits for these attributes

'Scale from 0 to 1 where 1 represents the ideal situation

a
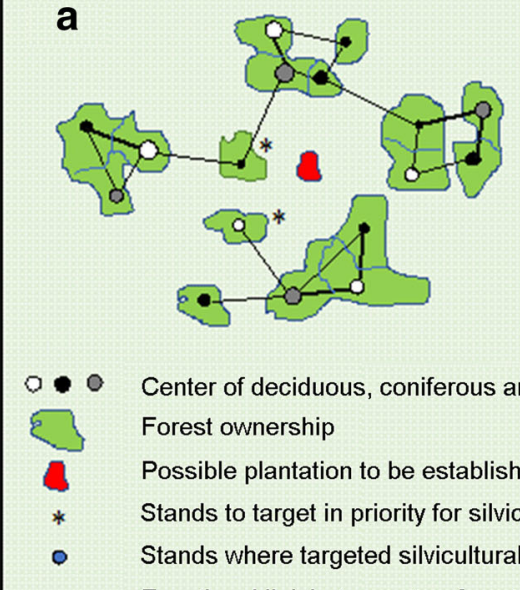

Center of deciduous, coniferous and mixed stands, respectively

\section{Forest ownership}

Possible plantation to be established from a non-forested site

Stands to target in priority for silvicultural operations

Stands where targeted silvicultural operations were held

Functional link between two forest stands

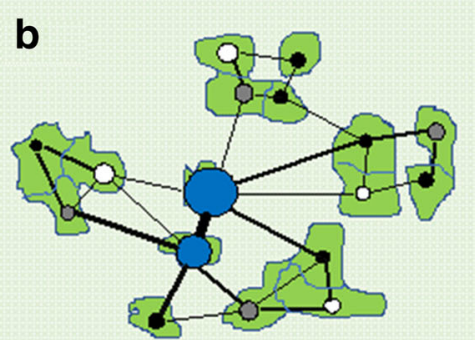

Fig. 4 Schematic representation of the analysis of a fictive forested landscape before (a) and after (b) targeted silvicultural interventions. Three attributes related to the resilience of the territory are represented: the functional diversity (related to the average size of the dots), connectivity (related to the total number and the average thickness of the links between dots), and centrality (related to the average number of links per dot). By prioritizing stands in which interventions will have the greatest impact at the scale of the territory (shown with an asterisk) or by adding a new stand with tree species with key functional traits (red stand), it is possible to switch from a landscape with a low resilience (a) to one with a higher resilience (b). Thus, by promoting tree species, through forest cutting or planting, with important and/or key missing functional traits in the most central stands (blue dots), one can increase the functional diversity, connectivity, and centrality of the landscape. This figure illustrates the situation at time 0 (before the possible dispersion of functional traits (by seeds) to adjacent stands) so the values of the different functional and spatial network attributes may change and improve over time across the whole territory (modified from Messier et al. 2018). Functional and spatial network indices for the two landscape scenarios: a Landscape with a low overall resilience and with low functional diversity (e.g., average value of 0.17 ), average connectivity (19 relatively weak links) and a low centrality (2.35 links per dot). $\mathbf{b}$ Territory with a good overall resilience with a good functional diversity (e.g., value of 2.3), good connectivity (26 links with many of them being strong) and a high centrality (2.94 links per dot) 
landscape to consider dynamic changes occurring both at the stand and landscape scales (Martensen et al. 2017; Saura 2018). Simulation modelling could also be used to determine what type of silvicultural interventions should be performed and where to obtain the desirable objectives over time and over a large spectrum of possible future scenarios (Ruppert et al. 2016; Aquilué 2018).

As a first rule to link stand and landscape scales, managers may choose to intervene in stands and/or forest ownerships having the lowest functional diversity while prioritizing those that can positively affect most of the selected indicators at the landscape level (e.g., the two stands with an asterisk in Fig. 4a). Here, the objective is to favour or add tree species with key missing functional traits or which are known to be resilient to current and known future stressors and would greatly contribute to the whole network's functional connectivity (Aquilué 2018). Increasing the diversity and functional redundancy of these two stands, while favouring species that are already present but not abundant on the territory or planting new species with complementary functional traits, results in the most efficient increase in functional connectivity (i.e., the level of functional traits that can be moved rapidly) over the landscape (Fig. 4b). In a highly fragmented forested landscape or forest ownership matrix, it may be advisable to establish new stands (red stand in Figs. 3 and 4) to increase the connectivity and centrality of the landscape. These new stands would be characterized by the presence of one or more tree species with complementary functional traits that were so far missing in the landscape. The end result will be a more purposefully designed functional network with self-regulating processes promoting forests more resilient to various threats thus limiting the need to intervene in the future to restore heavily impacted stands.

As discussed before, no silvicultural system or practice is a priori excluded from such an approach and a diversity of treatments is encouraged or even required. However, it is necessary to assess all interventions at both the stand and landscape levels to determine if they contribute to the overall functional connectivity and, consequently, forest resilience. For example, although mixed plantations are encouraged when establishing new stands, the approach does not preclude the use of monospecific plantations, if the species planted contributes an important set of functional traits and the location of the plantation results in improved connectivity, centrality, and modularity of the overall landscape.

Incorporating new tree species, provenances, and/or hybrids as part of a resilience trait-based assisted migration strategy (see the section "Promising approaches and concepts for the future") needs to be seriously considered for the positive and negative effects it could have in increasing the functional connectivity, resilience and/or flexibility of other options. In some parts of the world, the number of tree species naturally present is small and often composed of functionally similar species. In such cases, it is likely important to add new tree species having complementary functional traits to increase resilience to a wide variety of perturbations. Therefore, future integrated management approaches should use the concept of assisted migration in conjunction with species mixtures in the context of resilience trait-based assisted migration. The focal aim of this management option would be to build climate- and disturbance-resilient forests by introducing new functional attributes to the system while at the same time preserving key ecosystem functions and related services such as timber production and biodiversity.

This novel integrated approach, that we call "the functional complex network approach" reconciles traditional practices with new challenges, including the need to manage some protected areas to ensure they will continue to achieve their objective of preservation of biodiversity and ecological processes. Leaving aside forest management and silvicultural approaches based on command and control, determinism and predictability in our forests, the basis of this approach is to accept that different elements and behaviours that are intrinsic to forests are inevitable sources of uncertainty (Messier et al. 2016). In fact, multiple ecological processes governing forests are strongly related to stochasticity and randomness (e.g., seed survival, herbivory), are affected by factors occurring outside the system under management (e.g., forest fires, large-scale insect outbreaks), and/or follow a nonlinear dynamic thus creating an inability to accurately predict future population evolution. Such complex structures and dynamics are inherent in complex adaptive systems and at the root of the heterogeneity and therefore the resilience of forests, allowing them to better adapt to present and future biotic and abiotic conditions. A wider range of possible trajectories for different stands can then be accepted (see Fig. 5), while ensuring that the forest landscapes as a whole provide the desired ecosystem services, maybe even with less effort and interventions from foresters. By adopting such a strategy, not only would foresters have more flexibility in their practices, but they could also take advantage of self-organization dynamics and thus the natural adaptability of forests.

Although the examples provided in this paper are for fragmented forested landscapes (i.e., binary landscape of forest patch-island/node and static agriculture matrix background), the same approach can be used within continuous forested landscapes where a targeted forested type is considered as patch/node and all the forest types have a resistant/cost/friction values that either impede or facilitate (Fall et al. 2007; Dale and Fortin 2010) seed dispersion and/or establishment. In such cases, the landscape is composed of a mosaic of forest stands made up of different species assemblages and/or situated in 


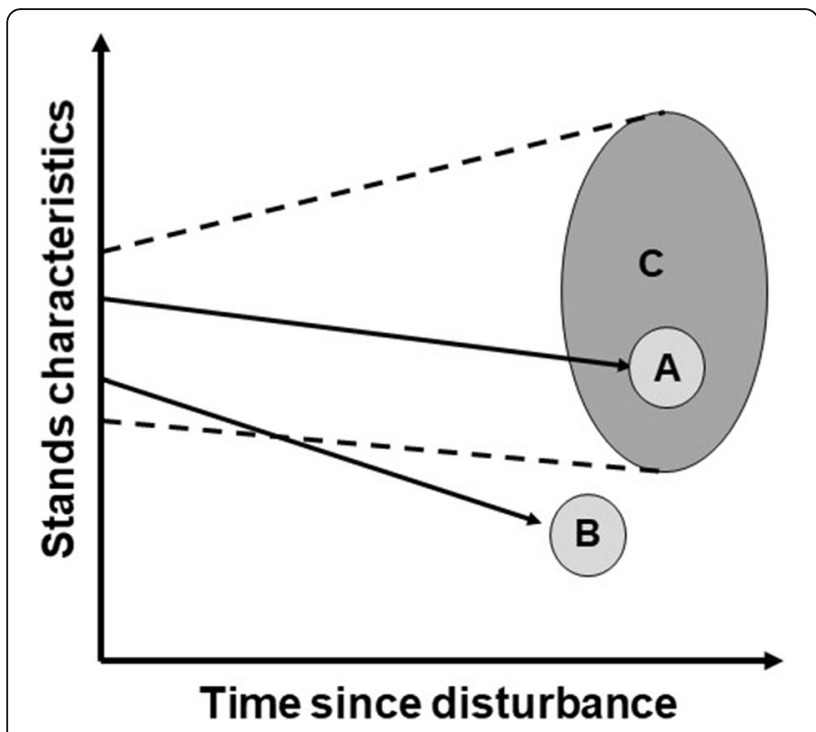

Fig. 5 Representations of different forest stands with various trajectories following forest harvesting. The stand characteristics (y-axis) represent various stand structures, compositions and volumes as well as habitats for living creatures. The stand trajectory to point A could represent a forest managed through single-tree selection, while the trajectory to point B could represent a similar forest managed as an intensive evenaged and single-species plantation, which has consequently a very small envelope of ecological characteristics. In both cases, ecological characteristics develop in a narrow predictable manner due to continuous and intensive management input, but stand A has more structural and compositional complexity than stand B. The shaded ellipse represented by $C$ shows the envelope of possible conditions that any stand can have within a region if the stands are allowed to self-organize following some level of management (such as enrichment planting to introduce tree species with important functional traits and some commercial thinning or partial cutting to maintain an uneven-aged structure and even greater diversity of tree species with different functional traits). The variety of possible outcomes within envelope $\mathrm{C}$ allows forests and foresters to be "creative" in adapting to new altered conditions such as climate change. Note that the final envelope (dashed lines) covers a different spectrum of ecological characteristics than the initial conditions since future climatic conditions will be different (modified from Puettmann et al. 2009) various topographical positions, and functional links are established among adjacent stands depending on the seed-borne functional traits that can be dispersed from one stand to another via multiple possible pathways, as shown in Fig. 4 for the two or three adjacent stands being part of a same continuous forest ownership.

\section{Conclusion}

The approach presented here is not intended to be a universal recipe or even the promotion of a new type of forestry, but rather an innovative and flexible way of integrating past, present and proposed forestry practices at a large and integrated spatial scale. It also brings the recent notions of functional diversity and complex spatial network together in a new way that facilitates decision making in terms of forest management. Incorporating these concepts into forest management planning would help to better prepare forest systems for the impending and ever-increasing socio-environmental uncertainties and threats. By relaxing control over forest composition and dynamics, allowing more flexibility in our practices and a larger set of desirable tree species, the natural abilities of forests to function and adapt will be strengthened, as well as their ability to provide the majority of ecosystem services the society may expect. The role of foresters within this new approach is that of a true steward of the forest who enhances its resilience to global changes.

\section{Acknowledgements}

Not applicable.

\section{Funding}

Funding for this study was provided in part by the Humboldt Foundation which provided money for an extensive stay in Germany to CM where part of the paper was written and by the Swiss National Science Foundation through a post-doctoral fellowship to MM.

\section{Availability of data and materials}

The datasets used and/or analysed during the current study are available from the corresponding author on reasonable request.

\section{Authors' contributions}

CM developed the overall idea and structure of the paper and all co-authors (JB, FD, FM, RSS, PN, MM, NA, MJF and KP) provided feedbacks on the proposed structure. CM wrote the first draft of the Abstract and Introduction. RSS and PN wrote the first draft of the section "Focus and limitations of past and current silvicultural and forest management approaches". HP wrote the first draft of the section "Managing forests as complex adaptive systems". FM and NA wrote the first draft of the section "Functional diversity: a new way of managing tree diversity in forests". MM wrote the first draft of the section "Assisted migration of tree species: bringing new traits and genes to cope with global changes". FD and MM wrote the first draft of the section "Managing for resilience: acknowledging global changes". CM, MJF and NA wrote the first draft of the section "The functional complex network approach: a landscape-level approach for managing forest for resilience in the Anthropocene". CM wrote the first draft of the Conclusion. CM and all co-authors revised and commented on all sections several times. All authors read and approved the final manuscript.

Ethics approval and consent to participate Not applicable.

\section{Consent for publication}

Not applicable.

\section{Competing interests}

The authors declare that they have no competing interests.

\section{Author details}

${ }^{1}$ Département des sciences naturelles and Institut des sciences de la forêt tempérée (ISFORT), Université du Québec en Outaouais (UQO), 58 rue Principale, Ripon, QC JOV 1VO, Canada. ${ }^{2}$ Centre d'étude de la forêt, Université du Québec à Montréal (UQAM), Case postale 8888, succursale Centre-Ville, Montréal, QC H3C 3P8, Canada. ${ }^{3}$ Chair of Silviculture, Institute of Forest Sciences, University of Freiburg, Tennenbacherstr. 4, 79106 Freiburg, Germany. ${ }^{4}$ Swiss Federal Institute for Forest, Snow and Landscape Research WSL, Birmensdorf, Switzerland. ${ }^{5}$ Department of Ecology and Evolution, University of Toronto, Toronto, ON M5S 3B2, Canada. ${ }^{6}$ Department of Ecosystems and Society, Oregon State University, Corvallis, OR 97331, USA. 
Received: 15 June 2018 Accepted: 19 February 2019

\section{Published online: 09 April 2019}

\section{References}

Angeler DG, Allen CR (2016) Quantifying resilience. J Appl Ecol 53(3):617-624. https://doi.org/10.1111/1365-2664.12649

Aplet GH, Johnson N, Olson JT, Sample VA (1993) Defining sustainable forestry. Island Press, Washington, DC

Aquilué N (2018) Managing forest landscapes under global changes: simulation models for scenario evaluation. Ph.D. thesis. Université du Québec à Montréal, Canada

Aubin I, Boisvert-Marsh L, Kebli H, McKenney D, Pedlar J, Lawrence K, Hogg EH, Boulanger Y, Gauthier S, Ste-Marie C (2018) Tree vulnerability to climate change: improving exposure-based assessments using traits as indicators of sensitivity. Ecosphere 9(2):e02108. https://doi.org/10.1002/ecs2.2108

Aubin I, Gachet S, Messier C, Bouchard A (2007) How resilient are northern hardwood forests to human disturbance? An evaluation using a plant functional group approach. Ecoscience 14(2):259-271. https://doi.org/10. 2980/1195-6860(2007)14[259:HRANHF]2.0.CO;2

Aubin I, Garbe CM, Colombo S, Drever CR, McKenney DW, Messier C, Pedlar J, Saner MA, Venier L, Wellstead AM, Winder R, Witten E, Ste-Marie C (2011) Why we disagree about assisted migration: ethical implications of a key debate regarding the future of Canada's forests. Forest Chron 87(6):755-765. https://doi.org/10.5558/tfc2011-092

Aubin I, Messier C, Gachet S, Lawrence K, McKenney D, Arseneault A, Bell W, De Grandpré L, Shipley B, Ricard JP, Munson A (2012) TOPIC-traits of plants in Canada. Natural Resources Canada, Canadian Forest Service, Sault Ste Marie http://www.nrcan.gc.ca/forests/research-centres/glfc/20303. Accessed 12 Oct 2018

Aubin I, Munson AD, Cardou F, Burton PJ, Isabel N, Pedlar JH, Paquette A, Taylor AR, Delagrange S, Kebli H, Messier C, Shipley B, Valladares F, Kattge J, Boisvert-Marsh L, McKenney D (2016) Traits to stay, traits to move: a review of functional traits to assess sensitivity and adaptive capacity of temperate and boreal trees to climate change. Environ Rev 24(2):164-186

Bauhus J, Forrester DI, Gardiner B, Jactel H, Vallejo R, Pretzsch H (2017a) Ecological stability of mixed-species forests. In: Pretzsch H, Forrester Dl, Bauhus J (eds) Mixed-species forests - ecology and management. Springer Verlag Germany, Heidelberg, pp 337-382

Bauhus J, Forrester DI, Pretzsch H (2017b) Mixed-species forests: the development of a forest management paradigm. In: Pretzsch H, Forrester DI, Bauhus J (eds) Mixed-species forests - ecology and management. Springer Verlag Germany, Heidelberg, pp 1-25

Bauhus J, Kouki J, Paillet Y, Asbeck T, Marchetti M (2017c) How does the forest-based bioeconomy impact forest biodiversity? In: Winkel G (ed) Towards a sustainable European forest-based bioeconomy - assessment and the way forward. What Science Can Tel Us, vol 8. European Forest Institute, Joensuu, pp 67-76

Bauhus J, Puettmann KJ, Kühne C (2013) Close-to-nature forest management in Europe: does it support complexity and adaptability of forest ecosystems. In: Messier C, Puettmann KJ, Coates KD (eds) Managing forests as complex adaptive systems: building resilience to the challenge of global change. Routledge, London, pp 187-213. https://doi.org/10.4324/9780203122808

Behan RW (1967) The succotash syndrome, or multiple use: a heartfelt approach to forest land management. Nat Resour J 7(4):473-484

Bengston DN (1994) Changing forest values and ecosystem management. Soc Nat Resour 7(6):515-533. https://doi.org/10.1080/08941929409380885

Bergeron Y, Harvey B, Leduc A, Gauthier S (1999) Forest management guidelines based on natural disturbance dynamics: stand-and forest-level considerations. Forest Chron 75(1):49-54. https://doi.org/10.5558/tfc75049-1

Canadell JG, Raupach MR (2008) Managing forests for climate change mitigation. Science 320(5882):1456-1457. https://doi.org/10.1126/science.1155458

Castagneyrol B, Jactel H, Vacher C, Brockerhoff EG, Koricheva J (2014) Effects of plant phylogenetic diversity on herbivory depend on herbivore specialization. J Appl Ecol 51(1):134-141. https://doi.org/10.1111/1365-2664.12175

Chapin FS, Pickett STA, Power ME, Jackson RB, Carter DM, Duke C (2011) Earth stewardship: a strategy for social-ecological transformation to reverse planetary degradation. J Env Stud Sci 1(1):44-53. https://doi.org/10.1007/ s13412-011-0010-7

Chazdon RL, Brancalion PHS, Lamb D, Laestadius L, Calmon M, Kumar C (2017) A policy-driven knowledge agenda for global Forest and landscape restoration. Conserv Lett 10(1):125-132. https://doi.org/10.1111/conl.12220
Ciancio O, Nocentini S (2011) Biodiversity conservation and systemic silviculture: concepts and applications. Plant Biosyst 145(2):411-418. https://doi.org/10. 1080/11263504.2011.558705

Conrad M (1983) Adaptability: the significance of variability from molecule to ecosystem. Plenum Press, New York

Craven D, Filotas E, Angers VA, Messier C (2016) Evaluating resilience of tree communities in fragmented landscapes: linking functional response diversity with landscape connectivity. Divers Distrib 22(5):505-518. https://doi.org/10. $1111 /$ ddi.12423

D'Amato AW, Jokela EJ, O'Hara KL, Long JN (2017) Silviculture in the United States: an amazing period of change over the past 30 years. J For 116(1):55-67. https://doi.org/10.5849/JOF-2016-035

Dale MRT, Fortin MJ (2010) From graphs to spatial graphs. Annu Rev Ecol Evol Syst 41:21-38

DeFries R, Nagendra H (2017) Ecosystem management as a wicked problem. Science 356(6335):265-270. https://doi.org/10.1126/science.aal1950

Delmas E, Besson M, Brice M-H, Burkle L, Riva GVD, Fortin M-J, Gravel D, Guimaraes P, Hembry D, Newman E, Olesen JM, Pires M, Yeakel JD, Poisot T (2018) Analyzing ecological networks of species interactions. Biol Rev. https://doi.org/10.1111/brv.12433

DeRose RJ, Long JN (2014) Resistance and resilience: a conceptual framework for silviculture. For Sci 60(6):1205-1212. https://doi.org/10.5849/forsci.13-507

Duncker PS, Barreiro SM, Hengeveld GM, Lind T, Mason WL, Ambrozy S, Spiecker H (2012) Classification of forest management approaches: a new conceptual framework and its applicability to European forestry. Ecol Soc 17(4):51. https://doi.org/10.5751/ES-05262-170451

Duveneck MJ, Scheller RM (2015) Climate-suitable planting as a strategy for maintaining forest productivity and functional diversity. Ecol Appl 25(6): 1653-1668. https://doi.org/10.1890/14-0738.1

Duveneck MJ, Scheller RM (2016) Measuring and managing resistance and resilience under climate change in northern great Lake forests (USA). Landsc Ecol 31(3):669-686. https://doi.org/10.1007/s10980-015-0273-6

Dymond CC, Tedder S, Spittlehouse DL, Raymer B, Hopkins K, McCallion K, Sandland J (2014) Diversifying managed forests to increase resilience. Can J For Res 44(10):1196-1205

Fahey RT, Alveshere BC, Burton Jl, D'Amato AW, Dickinson YL, Keeton WS, Kern CC, Larson AJ, Palik BJ, Puettmann KJ, Saunders MR, Webster CR, Atkins JW, Gough CM, Hardiman BS (2018) Shifting conceptions of complexity in forest management and silviculture. Forest Ecol Manag 421:59-71. https://doi.org/ 10.1016/j.foreco.2018.01.011

Fall A, Fortin M-J, Manseau M, O'Brien D (2007) Spatial graphs: principles and applications for habitat connectivity. Ecosystems 10:448-461

Filotas E, Parrott L, Burton PJ, Chazdon RL, Coates KD, Coll L, Haeussler S, Martin K, Nocentini S, Puettmann K, Putz FE, Simard SW, Messier C (2014) Viewing forests through the lens of complex systems science. Ecosphere 5(1):1-23. https://doi.org/10.1890/ES13-00182.1

Franklin JF (1989) The "new forestry". J Soil Water Conserv 44(6):549

Franklin JF, Mitchell RJ, Palik BJ (2007) Natural disturbance and stand development principles for ecological forestry. Gen. Tech. Rep. NRS-19. U.S. Department of Agriculture, Forest Service, Northern Research Station, Newtown Square. https://doi.org/10.2737/NRS-GTR-19

Gamfeldt L, Snäll T, Bagchi R, Jonsson M, Gustafsson L, Kjellander P, Ruiz-Jaen MC Fröberg M, Stendahl J, Philipson CD, Mikusiński G, Andersson E, Westerlund B, Andrén H, Moberg F, Moen J, Bengtsson J (2013) Higher levels of multiple ecosystem services are found in forests with more tree species. Nat Commun 4:1340. https://doi.org/10.1038/ncomms2328

Grassi G, House J, Dentener F, Federici S, den Elzen M, Penman J (2017) The key role of forests in meeting climate targets requires science for credible mitigation. Nat Clim Change 7:220-226. https://doi.org/10.1038/ nclimate 3227

Halofsky JE, Andrews-Key SA, Edwards JE, Johnston MH, Nelson HW, Peterson DL, Schmitt KM, Swanston CW, Williamson TB (2018) Adapting forest management to climate change: the state of science and applications in Canada and the United States. Forest Ecol Manag 421:84-97. https://doi.org/ 10.1016/j.foreco.2018.02.037

Halofsky JE, Peterson DL, Metlen KL, Myer MG, Sample VA (2016) Developing and implementing climate change adaptation options in forest ecosystems: a case study in southwestern Oregon, USA. Forests 7:268

Hof AR, Dymond CC, Mladenoff DJ (2017) Climate change mitigation through adaptation: the effectiveness of forest diversification by novel tree planting regimes. Ecosphere 8(11):e01981. https://doi.org/10.1002/ecs2.1981 
Ingrisch J, Bahn M (2018) Towards a comparable quantification of resilience. Trends Ecol Evol 33(4):251-259. https://doi.org/10.1016/j.tree.2018.01.013

Jacobsen MK (2001) History and principles of close to nature forest management: a central European perspective. In: Textbook 2 - Tools for Preserving Woodland Biodiversity. Naconex, pp 56-60

Jactel H, Bauhus J, Boberg J, Bonal D, Castagneyrol B, Gardiner B, GonzalezOlabarria JR, Koricheva J, Meurisse N, Brockerhoff EG (2017) Tree diversity drives forest stand resistance to natural disturbances. Curr Forestry Rep 3(3): 223-243. https://doi.org/10.1007/s40725-017-0064-1

Kohm KA, Franklin JF (1997) Creating a forestry for the 21st century: the science of ecosystem management. Island Press, Washington DC

Konnert M, Fady B, An Gömöry D, A'hara S, Wolter F, Ducci F, Koskela J, Bozzano M, Maaten T, Kowalczyk J (2015) Use and transfer of forest reproductive material in Europe in the context of climate change. European Forest Genetic Resources Programme (EUFORGEN), Bioversity International, Rome

Kuuluvainen T, Tahvonen O, Aakala T (2012) Even-aged and uneven-aged forest management in boreal Fennoscandia: a review. Ambio 41(7):720-737. https://doi.org/10.1007/s13280-012-0289-y

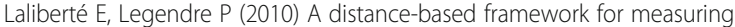
functional diversity from multiple traits. Ecology 91(1):299-305

Laughlin DC, Strahan RT, Huffman DW, Sánchez Meador AJ (2017) Using trait-based ecology to restore resilient ecosystems: historical conditions and the future of montane forests in western North America. Restor Ecol 25(SI2):S135-S146

Lexer MJ, Brooks RT (2005) Decision support for multiple purpose forestry. Forest Ecol Manag 207:1-3. https://doi.org/10.1016/j.foreco.2004.11.002

Liang J, Crowther TW, Picard N, Wiser S, Zhou M, Alberti G, Schulze E-D, McGuire $A D$, Bozzato F, Pretzsch $H$, de-Miguel S, Paquette A, Hérault B, SchererLorenzen M, Barrett CB, Glick HB, Hengeveld GM, Nabuurs G-J, Pfautsch S, Viana H, Vibrans AC, Ammer C, Schall P, Verbyla D, Tchebakova N, Fischer M, Watson JV, HYH C, Lei X, Schelhaas M-J, Lu H, Gianelle D, Parfenova El, Salas C, Lee E, Lee B, Kim HS, Bruelheide H, Coomes DA, Piotto D, Sunderland T, Schmid B, Gourlet-Fleury S, Sonké B, Tavani R, Zhu J, Brandl S, Vayreda J, Kitahara F, Searle EB, Neldner VJ, Ngugi MR, Baraloto C, Frizzera L, Bałazy R, Oleksyn J, Zawiła-Niedźwiecki T, Bouriaud O, Bussotti F, Finér L, Jaroszewicz B, Jucker T, Valladares F, Jagodzinski AM, Peri PL, Gonmadje C, Marthy W, O'Brien T, Martin EH, Marshall AR, Rovero F, Bitariho R, Niklaus PA, AlvarezLoayza P, Chamuya N, Valencia R, Mortier F, Wortel V, Engone-Obiang NL, Ferreira LV, Odeke DE, Vasquez RM, Lewis SL, Reich PB (2016) Positive biodiversity-productivity relationship predominant in global forests. Science 354:aaf8957. https://doi.org/10.1126/science.aaf8957

Lindenmayer DB, Franklin JF, Lõhmus A, Baker SC, Bauhus J, Beese W, Brodie A, Kiehl B, Kouki J, Pastur GM, Messier C, Neyland M, Palik B, Sverdrup-Thygeson A, Volney J, Wayne A, Gustafsson L (2012) A major shift to the retention approach for forestry can help resolve some global forest sustainability issues. Conserv Lett 5(6):421-431. https://doi.org/10.1111/j.1755-263X.2012.00257.x

Lindner M, Maroschek M, Netherer S, Kremer A, Barbati A, Garcia-Gonzalo J, Seidl R, Delzon S, Corona P, Kolström M, Lexer MJ, Marchetti M (2010) Climate change impacts, adaptive capacity, and vulnerability of European forest ecosystems. Forest Ecol Manag 259(4):698-709

Martensen AC, Saura S, Fortin M-J (2017) Spatio-temporal connectivity: assessing the amount of reachable habitat in dynamic landscapes. Methods Ecol Evol 8(10):1253-1264. https://doi.org/10.1111/2041-210X.12799

Messier C, Maure F, Aquilué N (2018) Une nouvelle approche pour immuniser nos forêts contre l'incertitude. J Forestier Suisse 169(4):199-202

Messier C, Puettmann KJ, Chazdon R, Andersson KP, Angers VA, Brotons L, Filotas E, Tittler R, Parrott L, Levin SA (2015) From management to stewardship: viewing forests as complex adaptive systems in an uncertain world. Conserv Lett 8(5):368-377. https://doi.org/10.1111/conl.12156

Messier C, Puettmann KJ, Coates KD (2013) Managing forests as complex adaptive systems: building resilience to the challenge of global change. Routledge, New York

Messier C, Puettmann KJ, Filotas E, Coates KD (2016) Dealing with non-linearity and uncertainty in forest management. Curr Forestry Rep 2(2):150-161. https://doi.org/10.1007/s40725-016-0036-x

Messier C, Tittler R, Kneeshaw DD, Gélinas N, Paquette A, Berninger K, Rheault H, Meek P, Beaulieu N (2009) TRIAD zoning in Quebec: experiences and results after 5 years. Forest Chron 85(6):885-896

Millar Cl, Stephenson NL, Stephens SL (2007) Climate change and forests of the future: managing in the face of uncertainty. Ecol Appl 17(8):2145-2151

Mina M, Bugmann H, Cordonnier T, Irauschek F, Klopcic M, Pardos M, Cailleret M (2017) Future ecosystem services from European mountain forests under climate change. J Appl Ecol 54(2):389-401. https://doi.org/ $10.1111 / 1365-2664.12772$

Mina M, Huber MO, Forrester Dl, Thürig E, Rohner B (2018) Multiple factors modulate tree growth complementarity in central European mixed forests. J Ecol 106(3):1106-1119. https://doi.org/10.1111/1365-2745.12846

Mitchell SJ, Beese WJ (2002) The retention system: reconciling variable retention with the principles of silvicultural systems. Forest Chron 78(3):397-403. https://doi.org/10.5558/tfc78397-3

Nabuurs G-J, Delacote P, Ellison D, Hanewinkel M, Hetemäki L, Lindner M (2017) By 2050 the mitigation effects of EU forests could nearly double through climate smart forestry. Forests 8(12):484

Nagel LM, Palik BJ, Battaglia MA, D'Amato AW, Guldin JM, Swanston CW, Janowiak MK, Powers MP, Joyce LA, Millar Cl, Peterson DL, Ganio LM, Kirschbaum C, Roske MR (2017) Adaptive silviculture for climate change: a national experiment in manager-scientist partnerships to apply an adaptation framework. J For 115(3):167-178. https://doi.org/10.5849/jof.16-039

Newman MEJ (2006) Modularity and community structure in networks. Pans 103(23):8577-8582. https://doi.org/10.1073/pnas.0601602103

Nocentini S, Buttoud G, Ciancio O, Corona P (2017) Managing forests in a changing world: the need for a systemic approach. A review. Forest Syst 26(1):eR01. https://doi.org/10.5424/fs/2017261-09443

Nolet P, Kneeshaw DD, Messier C, Béland M (2017) Comparing the effects of even-and uneven-aged silviculture on ecological diversity and processes: a review. Ecol Evol 8(2):1217-1226. https://doi.org/10.1002/ece3.3737

O'Hara KL (2016) What is close-to-nature silviculture in a changing world? Forestry 89(1):1-6. https://doi.org/10.1093/forestry/cpv043

Oliver CD (2003) Sustainable forestry: what is it? How do we achieve it? J For 101(5):8-14

Park A, Talbot C (2018) Information underload: ecological complexity, incomplete knowledge, and data deficits create challenges for the assisted migration of forest trees. BioScience 68(4):251-263

Pedlar JH, McKenney DW, Aubin I, Beardmore T, Beaulieu J, Iverson L, O'Neill GA, Winder RS, Ste-Marie C (2012) Placing forestry in the assisted migration debate. Bioscience 62(9):835-842. https://doi.org/10.1525/bio.2012.62.9.10

Pedlar JH, McKenney DW, Beaulieu J, Colombo S, McLachlan J, O'Neill GA (2011) The implementation of assisted migration in Canadian forests. Forest Chron 87(6):766-777. https://doi.org/10.5558/tfc2011-093

Peters DPC, Lugo AE, Chapin SS III, Pickett STA, Duniway M, Rocha AV, Swanson FJ, Laney C, Jones J (2011) Cross-system comparisons elucidate disturbance complexities and generalities. Ecosphere 2:Article 81.

Pinkerton E (1998) Integrated management of a temperate montane forest ecosystem through wholistic forestry: a British Columbia example. In: Berkes F (ed) Linking social and ecological systems: management practices and social mechanisms for building resilience. Cambridge University Press, New York, pp 363-389

Pommerening A, Murphy ST (2004) A review of the history, definitions and methods of continuous cover forestry with special attention to afforestation and restocking. Forestry 77(1):27-44. https://doi.org/10.1093/forestry/77.1.27

Pretzsch H, Forrester DI, Bauhus J (2017) Mixed-species forests - ecology and management. Springer Verlag Germany, Heidelberg

Puettmann KJ (2014) Restoring the adaptive capacity of forest ecosystems. J Sustain Forest 33(sup1):S15-S27

Puettmann KJ, Coates KD, Messier C (2009) A critique of silviculture: managing for complexity. Island Press, Washington

Puettmann KJ, Parrott L, Messier C (2016) Teaching complex adaptive systems science in natural resource management: examples from forestry. Nat Sci Educ 45(1). https://doi.org/10.4195/nse2016.04.0009

Puettmann KJ, Tappeiner JC (2013) Multi-scale assessments highlight silvicultural opportunities to increase species diversity and spatial variability in forests. Forestry 87(1):1-10

Puettmann KJ, Wilson SM, Baker SC, Donoso PJ, Drössler L, Amente G, Harvey BD, Knoke T, Lu Y, Nocentini S, Putz FE, Yoshida T, Bauhus J (2015) Silvicultural alternatives to conventional even-aged forest management-what limits global adoption? Forest Ecosyst 2:8. https://doi. org/10.1186/s40663-015-0031-x

Ratcliffe S, Wirth C, Jucker T, van der Plas F, Scherer-Lorenzen M, Verheyen K, Allan E, Benavides R, Bruelheide H, Ohse B, Paquette A, Ampoorter E, Bastias CC, Bauhus J, Bonal D, Bouriaud O, Bussotti F, Carnol M, Castagneyrol B, Chećko E, Dawud SM, Wandeler H, Domisch T, Finér L, Fischer M, Fotelli M, Gessler A, Granier A, Grossiord C, Guyot V, Haase J, Hättenschwiler S, Jactel H, Jaroszewicz B, Joly F-X, Kambach S, Kolb S, Koricheva J, 
Liebersgesell M, Milligan $H$, Müller $S$, Muys B, Nguyen D, Nock CA, Pollastrini M, Purschke O, Ragodlou K, Raulund-Rasmussen K, Roger F, Ruiz-Benito P, Seidl R, Selvi F, Seiferling I, Stenlid J, Valladares F, Vesterdal L, Baeten L (2017) Biodiversity and ecosystem functioning relations in European forests depend on environmental context. Ecol Lett 20(11):1414-1426. https://doi.org/10.1111/ele.12849

Rayfield B, Fortin M-J, Fall A (2010) The sensitivity of least-cost habitat graphs to relative cost surface values. Landsc Ecol 25(4):519-532

Ricotta C, de Bello F, Moretti M, Caccianiga M, Cerabolini BEL, Pavoine S (2016) Measuring the functional redundancy of biological communities: a quantitative guide. Methods Ecol Evol 7(11):1386-1395. https://doi.org/10. $1111 / 2041-210 \times .12604$

Ridley HN (1930) The dispersal of plants throughout the world. L. Reeve \& Company, Ashford

Ruppert JLW, Fortin M-J, Gunn EA, Martell DL (2016) Conserving woodland caribou habitat while maintaining timber yield: a graph theory approach. Can J For Res 46:914-923

Sasaki T, Furukawa T, Iwasaki Y, Seto M, Mori AS (2015) Perspectives for ecosystem management based on ecosystem resilience and ecological thresholds against multiple and stochastic disturbances. Ecol Indic 57:395408. https://doi.org/10.1016/j.ecolind.2015.05.019

Saura S (2010) Measuring connectivity in habitat mosaics: the equivalence of two existing network indices and progress beyond them. Community Ecol 11(2):217-222

Saura S (2018) Node self-connections in network metrics. Ecol Lett 21(2):319-320

Schulz BK, Gray AN (2013) The new flora of northeastern USA: quantifying introduced plant species occupancy in forest ecosystems. Environ Monit Assess 185(5):3931-3957

Seastedt TR, Hobbs RJ, Suding KN (2008) Management of novel ecosystems: are novel approaches required? Front Ecol Environ 6(10):547-553. https://doi.org/ 10.1890/070046

Seidl R, Spies TA, Peterson DL, Stephens SL, Hicke JA (2016) Searching for resilience: addressing the impacts of changing disturbance regimes on forest ecosystem services. J Appl Ecol 53(1):120-129. https://doi.org/10.1111/13652664.12511

Seidl R, Thom D, Kautz M, Martin-Benito D, Peltoniemi M, Vacchiano G, Wild J, Ascoli D, Petr M, Honkaniemi J, Lexer MJ, Trotsiuk V, Mairota P, Svoboda M, Fabrika M, Nagel TA, Reyer CPO (2017) Forest disturbances under climate change. Nat Clim Chang 7(6):395-402

Seymour RS, Hunter MLJ (1992) New forestry in eastern spruce-fir forests: principles and applications to Maine, vol 716. College of Forest Resources, University of Maine, USA

Seymour RS, Hunter MLJ (1999) Principles of ecological forestry. In: Hunter M (ed) Maintaining biodiversity in forest ecosystems. Cambridge University Press, Cambridge, pp 22-61

Sittaro F, Paquette A, Messier C, Nock CA (2017) Tree range expansion in eastern North America fails to keep pace with climate warming at northern range limits. Glob Chang Biol 23(8):3292-3301. https://doi.org/10.1111/gcb.13622

Standish RJ, Hobbs RJ, Mayfield MM, Bestelmeyer BT, Suding KN, Battaglia LL, Eviner V, Hawkes CV, Temperton VM, Cramer VA, Harris JA, Funk JL, Thomas PA (2014) Resilience in ecology: abstraction, distraction, or where the action is? Biol Conserv 177:43-51. https://doi.org/10.1016/j.biocon.2014.06.008

Steffen W, Crutzen PJ, McNeill JR (2007) The Anthropocene: are humans now overwhelming the great forces of nature. Ambio 36(8):614-621

Ste-Marie C, Nelson EA, Dabros A, Bonneau M-E (2011) Assisted migration: introduction to a multifaceted concept. Forest Chron 87(6):724-730

Thompson I, Mackey B, McNulty S, Mosseler A (2009) Forest resilience, biodiversity, and climate change. In: secretariat of the convention on biological diversity, Montreal. Technical Series no. 43, pp 1-67

Timpane-Padgham BL, Beechie T, Klinger T (2017) A systematic review of ecological attributes that confer resilience to climate change in environmental restoration. PLoS One 12(3):e0173812. https://doi.org/10.1371/ journal.pone.0173812

Urban DL, Minor ES, Treml EA, Schick RS (2009) Graph models of habitat mosaics. Ecol Lett 12(3):260-273

Valiente-Banuet A, Aizen MA, Alcántara JM, Arroyo J, Cocucci A, Galetti M, García MB, García D, Gómez JM, Jordano P, Medel R, Navarro L, Obeso JR, Oviedo R, Ramírez N, Rey PJ, Traveset A, Verdú M, Zamora R (2015) Beyond species loss: the extinction of ecological interactions in a changing world. Funct Ecol 29(3):299-307. https://doi.org/10.1111/1365-2435.12356 van der Plas F, Manning P, Allan E, Scherer-Lorenzen M, Verheyen K, Wirth C, Zavala MA, Hector A, Ampoorter E, Baeten L, Barbaro L, Bauhus J, Benavides R, Benneter A, Berthold F, Bonal D, Bouriaud O, Bruelheide H, Bussotti F, Carnol M, Castagneyrol B, Charbonnier Y, Coomes D, Coppi A, Bastias CC, Dawud SM, De Wandeler H, Domisch T, Finér L, Gessler A, Granier A, Grossiord C, Guyot V, Hättenschwiler S, Jactel H, Jaroszewicz B, Joly F-X, Jucker T, Koricheva J, Milligan H, Müller S, Muys B, Nguyen D, Pollastrini M, Raulund-Rasmussen K, Selvi F, Stenlid J, Valladares F, Vesterdal L, Zielínski D, Fischer M (2016) Jack-of-all-trades effects drive biodiversity-ecosystem multifunctionality relationships in European forests. Nat Commun 7:11109. https://doi.org/10.1038/ncomms11109

Vincent JR, Binkley CS (1993) Efficient multiple-use forestry may require land-use specialization. Land Econ 69(4):370-376

Violle C, Navas ML, Vile D, Kazakou E, Fortunel C, Hummel I, Garnier E (2007) Let the concept of trait be functional! Oikos 116(5):882-892. https://doi.org/10. 1111/j.0030-1299.2007.15559.x

Weih M (2004) Intensive short rotation forestry in boreal climates: present and future perspectives. Can J For Res 34(7):1369-1378

Wiersum KF (1995) 200 years of sustainability in forestry: lessons from history. Environ Manag 19(3):321-329

Williams MI, Dumroese RK (2013) Preparing for climate change: forestry and assisted migration. J For 111(4):287-297. https://doi.org/10.5849/jof.13-016

Yachi S, Loreau M (1999) Biodiversity and ecosystem productivity in a fluctuating environment: the insurance hypothesis. Proc Natl Acad Sci U S A 96(4):1463-1468

\section{Submit your manuscript to a SpringerOpen ${ }^{\circ}$ journal and benefit from:}

- Convenient online submission

- Rigorous peer review

- Open access: articles freely available online

- High visibility within the field

- Retaining the copyright to your article

Submit your next manuscript at $\boldsymbol{\nabla}$ springeropen.com 